\title{
Simultaneous Analysis of Chlorogenic Acid, Epicatechin Gallate, and Rosmarinic Acid from the LOL (Ligularia stenofelphala, Orostachts japonica, Lavandula anfustifola) Cosmetic Composite and its Antioxidative Activity
}

Ju Eun Kim ${ }^{1,2}$, Abinash Chandra Shrestha ${ }^{1}$, Youn Jeong Jo ${ }^{1}$, Jae Yoon Leem ${ }^{1,2^{*}}$

${ }^{1}$ College of Pharmacy, Woosuk University, Wanju-gun, Jeolabuk-do, Korea

${ }^{2}$ Institute of Smart Convergence Life-Care, Woosuk University, Wanju-gun, Jeolabuk-do, Korea

\author{
*Corresponding author: Jae Yoon Leem, \\ College of Pharmacy of Pharmacy, Woosuk \\ University, 443, Samnye-ro, Wanju-gun, \\ Jeolabuk-do 55338, Korea \\ Tel.: +82632901575 \\ Fax: +82632901561 \\ Email: jyleem@woosuk.ac.kr
}

Received April 23, 2021

Revised May 18, 2021

Accepted June 02, 2021

Published June 30, 2021

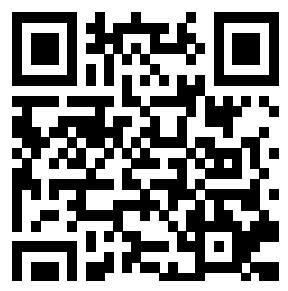

\begin{abstract}
Purpose: As the demand for natural cosmetics increases, properly managing production and quality control should be prioritized. Chlorogenic acid (CGA), epicatechin gallate (ECG), and rosmarinic acid (RMA) were selected to validate the cosmetic composite LOL, a mixture of $50 \%$ EtOH extract of Ligularia stenocephala (LS), Orostachys japonica (OJ), and Lavandula angustifolia (LA). Methods: Highperformance liquid chromatography with a diode array detector (HPLC-DAD) was used to simultaneously analyze the three LOL compounds from LOL (Ligularia stenocephala, Orostachys japonica, Lavandula angustifolia). Linearity, accuracy, and precision analyses were performed using HPLC-DAD, and the anti-oxidative effects were evaluated through a 2,2-diphenyl-1-picrylhydrazyl (DPPH) radical-scavenging assay. Results: All three extracts showed a high DPPH radical-scavenging effect, and the detected marker compounds showed significant linearity $\left(R^{2} \geq 0.9997\right)$. The limit of detection (LOD) of CGA, ECG, and RMA was $0.83 \mu \mathrm{g} / \mathrm{mL}, 0.33 \mu \mathrm{g} / \mathrm{mL}$, and 0.20 $\mu \mathrm{g} / \mathrm{mL}$, respectively. Meanwhile, the limit of quantification (LOQ) of CGA, ECG, and RMA was $2.51 \mu \mathrm{g} / \mathrm{mL}, 0.99 \mu \mathrm{g} / \mathrm{mL}$, and $0.61 \mu \mathrm{g} / \mathrm{mL}$, respectively. Method validation showed acceptable precision (intra-and inter-day precision, CGA, ECG, and RMA, 1.77, $1.42,0.80 \%$ and $1.09,0.72,1.42 \%$, respectively) and recovery (CGA, ECG, and RMA, 102.00\%-117.78\%, 94.40\%-108.06\%, and 93.79\%-107.05\%). Conclusion: The contents of the three markers were $13.99 \mu \mathrm{g} / \mathrm{mL} \mathrm{CGA}, 8.28 \mu \mathrm{g} / \mathrm{mL}$ ECG, and $8.40 \mu \mathrm{g} / \mathrm{mL}$ of RMA, respectively. This study also suggests that the developed method can validate the LOL cosmetic composition quality control process.
\end{abstract}

Keywords: Ligularia stenocephala, Orostachys japonica, Lavandula angustifolia, HPLC-DAD, Validation

\section{Introduction}

Recently, developments in biotechnology have brought about an increase in the demand for cosmetics manufactured from natural ingredients, including herbal medicine. Skin whitening cosmetics use organic materials, such as extracts of Vaccinium vitis-idaea or Broussonetia kazinoki, after hydroquinone was found to have carcinogenic properties.
The demand for multifunctional cosmetics is on the rise, and complex compositions of two or more organic materials have also been popularized (Chanchal \& Swarnlata, 2008). However, relevant technical needs and, quality control standards in manufacturing are insufficient. Without setting a benchmark for quality, various bodily mechanisms cannot be considered, and component destruction occurs during the distribution process based on raw material stability. A mixture of two incompatible 
ingredients may result in an antagonistic effect and without a proper understanding of these ingredients, products can become harmful to consumers (Espinosa-Leal \& Garcia-Lara, 2019; Mellou et al., 2019; Nohynek et al., 2010).

In Korea, standards and methods for testing the functional or active ingredients of functional food and herbal medicines have been legislated, but standardization is not yet required for natural cosmetics. If the natural extracts' raw materials cannot be disclosed accurate, the product' s reliability can be questioned. Therefore, a product' s quality must be assured to improve customer satisfaction (Chang, 2003).

Numerous analytical techniques have been used to quantify cosmetic ingredients through high-performance liquid chromatography (HPLC), such as HPLC coupled with other detectors, including ultraviolet (UV) detectors, mass spectrometers, and diode array detectors (DADs) (Papageorgiou et al., 2020). However, high-performance liquid chromatography with a diode array detector (HPLC-DAD) is highly recommended for analyzing herbal combinations because it offers 3D analyses and a wide array of mobile phases while being more affordable and resistant to contamination. This method is beneficial for simultaneously analyzing samples with mixed components with of different absorption wavelengths (Czerwińska et al., 2020; Elansary et al., 2019; Ham et al., 2018; Xiao et al., 2017).

This study attempted to develop a combination of natural cosmetic materials according to the recent increase in demand for natural cosmetics. A composite of LOL was prepared by securing $50 \%$ ethanol extracts of three medicinal herbs cultivated in Namwon city; Lavender (Lavandula anfustifolia) native to the west, narrow-head ragwort (Ligularia stenofelph), and rock pine (Orostachys japonica) native to the east. Each component's DPPH scavenging ability was measured, and a simultaneous analysis method of the index component of the combination LOL using HPLC-DAD was developed.

A Ligularia stenocephala (Maxim.) Matsum. \& Koiz (LS), Orostachys japonica (Maxim.) A. Berger (OJ), and Lavandula angustifolia Mill (LA) (LOL) composite contains 50\% EtOH extract of LS narrow-head ragwort, OJ rock pine, and LA lavender. According to the International Nomenclature of Cosmetic Ingredients (INCI), LS and OJ are named Ligularia stenocephala extract and Orostachys japonica extract, respectively.

The LS perennial herb, which belongs to the Asteraceae family, can be found in Korea (Jeollanam-do), Japan, Taiwan, and China. Young leaves are harvested and eaten as herbs, and in oriental medicine, the root is used as medicine for bowel disorders and gynecological diseases (Kim et al., 2012b). This herb has numerous benefits, including producing antioxidants, reducing melanin production, lessening wrinkles while also possessing hepatoprotective, anti-diabetic, and anti-ulcerogenic effects (Lee et al., 2010; Roh et al., 2009). Several phytochemicals identified from LS include N-phenyl-2naphthylamine, neophytadiene, vanillin, triterpenoid derivatives, 4-hydroxy-acetophenone, chlorogenic acid (CGA), and caffeic acid, ligulacephalins A, B, C, and euparin (Todoya et al., 2005).

The OJ of a perennial flowering plant in the Crassulaceae family, commonly referred to as a rock pine, is found on mountain rocks in Korea and Japan. The rock pine possesses anti-cancer properties (Kim et al., 2012a), enhances hepatic alcohol dehydrogenase (Hur \& Park, 2006), protects neuronal cells from apoptosis (Yoon et al., 2000), and demonstrates antioxidative (Choi et al., 2008) and anti-inflammatory, and inhibitory effects on collagenase, elastase, and tyrosinase (Im et al., 2017). Several phytochemicals identified in OJ include epicatechin, epicatechin gallate (ECG), gallic acid, kaempferol, kaempferol 3-O- $\alpha-1-$ rhamnopyranoside, quercetin, quercetin 3-O- $\beta-\mathrm{D}-$ glucopyranoside, and pyrogallol (Kim et al., 2008).

The LA belongs to the Lamiaceae family, and lavender essential oil has been used for treating neurological disorders and rheumatism while demonstrating antibacterial effects (Cavanagh \& Wilkinson, 2002; Ha et al., 2019). Lavender extract mixed in hot water and ethanol also contains antioxidants and display whitening and sebum inhibitory effects (Carrasco et al., 2016; Hus et al., 2007). The reported substances in LS include rosmarinic acid (RMA), luteolin, apigenin, apigenin 7-O$\beta-\mathrm{D}$-glucoside, luteolin 7-O- $\beta-\mathrm{D}$-glucuronide, linalool, linalyl acetate, (E)- $\beta$-caryophyllene, eucalyptol, and camphor (Zhao et al., 2015; Andrys et al., 2018).

This study aims to develop a new method that simultaneously analyzes each marker compound from the LOL composite using HPLC-DAD. Several validation methods were conducted, including tests for accuracy, specificity, precision, and the limit of detection (LOD), the limit of quantitation (LOQ), range, and linearity.

\section{Methods}

\section{Preparation of materials}


The samples of LS, OJ, and LA used in the composite were harvested and purchased in Namwon City (Korea). After drying at $40^{\circ} \mathrm{C}$ for $72 \mathrm{~h}$ with a dryer (LD9013; L'EQUIP Co., Korea), each herb was pulverized with a blender (HMF-3600TG; Hanil Electric, Korea). A total of $2 \mathrm{~L}$ of $50 \%$ ethanol per $100 \mathrm{~g}$ was used for extraction at $80^{\circ} \mathrm{C}$ for $4 \mathrm{~h}$, and the extract was filtered twice with nonwoven fabric and filter paper. The filtered extract used as a sample first was concentrated at $50^{\circ} \mathrm{C}$ with a vacuum concentrator (R-100; BUCHI, Switzerland), then freeze-dried with a freeze dryer (MCFD8508; Ilshin Biobase Co., Korea), which resulting in a $17 \%$ extraction yield. The three herbs used in the experiment were authenticated by Professor Dae Keun Kim of the Woosuk University's Department of Pharmacy.

\section{Reagents}

Standard CGA, ECG, and RMA (Biopurify Phytochemicals, China) with more than $98 \%$ purity were utilized for this study. In addition, the methanol and acetonitrile (J.T. Baker, Phillipsburg, USA) used in this study are HPLC-grade organic solvents, and the acid used was formic acid (Fluka, Germany).

\section{DPPH radical scavenging assay}

The DPPH radical scavenging activity was measured by using a modified Blois method (Blois, 1958). After adding 247.5 $\mu \mathrm{L}$ of a $0.2 \mathrm{mM}$ DPPH (Sigma-Aldrich, USA) solution to $2.5 \mu \mathrm{L}$ of the sample, a reaction occurs in the dark at room temperature for $20 \mathrm{~min}$. Measurements were taken at $517 \mathrm{~nm}$ using an ELISA reader (Bio-Rad, USA) after the reaction occurs. The sample's concentration when the absorbance of DPPH decreased by $50 \%$ $\left(\mathrm{RC}_{50}\right)$ was determined, and each sample was tested three times. L-ascorbic acid (Sigma-Aldrich) was the positive control (Ham et al., 2018).

\section{Pretreatment of samples}

For HPLC analysis, $20 \mathrm{mg}$ of an equal composite of the three extracts was taken and ultrasonically extracted with $1 \mathrm{~mL}$ of $70 \%$ methanol for $30 \mathrm{~min}$ before being filtered through a $0.2 \mu \mathrm{m}$ membrane filter (PALL Co., USA). The marker component of the standard product was also obtained similarly.

\section{Instrumentation and Chromatographic conditions}

For the marker components' qualitative and quantitative analyses, a Hitachi Chromaster HPLC CM5000 system (Hitachi, Japan) was used, and detection was performed at multiple wavelengths using a diode array detector (DAD). YMC-Pack ODS-AM, C18 column ( $250 \times 4.6$ mm i.d; YMC, Japan) was used at $40^{\circ} \mathrm{C}$. Its mobile phase was composed of water (A) containing $0.1 \%$ formic acid and acetonitrile (B) containing $0.1 \%$ formic acid with a flow rate of $1.0 \mathrm{~mL} / \mathrm{min}$. The slope of the mobile phase was 0-10 min, (A): 100\%, 10-55 min, (A): 60\%, 55-60 min, (A): 0\%, 60-65 min, (A): 0\%, 65-70 min, (A): 100\%. Detection wavelengths were set at $213 \mathrm{~nm}, 326 \mathrm{~nm}$, and $329 \mathrm{~nm}$, and HPLC data analysis was performed using Agilent Open Lab Software (Agilent, CA).

\section{Methodology validation}

The methodology was veridated by determining the linearity, range, LOD, LOQ, accuracy, precision, and content evaluation based on the Guidelines for Validation of Pharmaceutical Drugs from the Ministry of Food and Drug Safety (NIFDS, 2015).

\section{Linearity and range}

Linearity was evaluated by preparing a calibration curve and calculating a regression equation based on the results obtained after diluting the marker compounds a three different concentrations $(1,50$, and $100 \mu \mathrm{g} / \mathrm{mL})$.

\section{Specificity}

After preparing a composite of the three plant extracts and a standard mixture of each indicator component, the chromatogram was visually evaluated. The ultraviolet (UV) spectrum of the corresponding indicator component was assessed by extracting the standard mixture's chromatogram for comparison.

\section{Accuracy and precision}

Consequently, both accuracy and precision were measured by comparing the integral values of the marker compounds' peaks. The accuracy was evaluated by adding three different concentrations of the standard product to the sample before measuring the recovery rate. In comparison, precision was determined using relative standard deviation (RSD) through intraday and interday tests. Each experiment was evaluated by calculating the results' RSDs obtained through three repeated experiments with three concentrations of mixed standard solutions.

\section{Limit of detection (LOD) and limit of quantification (LOQ)}

The LOD and LOQ were calculated using the following 
<smiles>O=C(/C=C/c1ccc(O)c(O)c1)OC1CC(O)(C(=O)O)C[C@H](O)[C@H]1O</smiles>

Chlorogenic acid<smiles>O=C(O[C@H]1Cc2c(O)cc(O)cc2O[C@H]1c1ccc(O)c(O)c1)c1cc(O)c(O)c(O)c1</smiles>

Epicatechin gallate<smiles>O=C(/C=C/c1ccc(O)c(O)c1)O[C@H](Cc1ccc(O)c(O)c1)C(=O)O</smiles>

Rosmarinic acid

Figure 1. Chemical structure of marker compounds.

formula (Chanchal \& Swarnlata, 2008) based on the prepared calibration curve, where $\sigma$ is the standard deviation of the response and $\mathrm{S}$ is the slope of the calibration curve.

$\mathrm{LOD}=3.3(\sigma / \mathrm{S})$

$\mathrm{LOQ}=10(\sigma / \mathrm{S})$

\section{Content evaluation}

Based on the calibration curve obtained from the standard product analysis of the three marker compounds, each marker compound's area value was substituted with the linearity equation to calculate the marker compound's content.

\section{Result and Discussion}

\section{DPPH radical-scavenging activity}

Table 1 shows the sample's concentration required for $50 \%$ $\mathrm{DPPH}$ radical scavenging, which identifies the measured DPPH scavenging activities of the EtOH extract of LS, OJ, LA, and the composite. The OJ showed the highest DPPH scavenging activity of $48.21 \pm 4.0 \mu \mathrm{g} / \mathrm{mL}$ and its combination with LA showed $\mathrm{RC}_{50}$ at $58.06 \pm 1.3 \mu \mathrm{g} / \mathrm{mL}$. Meanwhile, the LOL composite showed $\mathrm{RC}_{50}$ at $67.73 \pm 2.6 \mu \mathrm{g} / \mathrm{mL}$, and the positive control L-ascorbic acid showed $\mathrm{RC}_{50}$ at $19.81 \mu \mathrm{g} / \mathrm{mL}$. Choi et al. (2008) reported that the $\mathrm{MeOH}$ extract of OJ could donate electrons, act as a reducing agent, and demonstrate the superoxide dismutaselike activity, suggesting that harvesting around August to October contributed to high anti-oxidative activityies. Im et al. (2017) reported that EtOH extracts of OJ inhibited the enzyme activities of collagenase, elastase, and tyrosinase by $85 \%$, $45 \%$, and $70 \%$, respectively, at a concentration of $500 \mu \mathrm{g} / \mathrm{mL}$. Meanwhile, Kim et al. (2012a) reported that the ethyl acetate fraction of $\mathrm{LS}$ had $\mathrm{RC}_{50}$ values of $280 \mu \mathrm{g} / \mathrm{mL}$ for $\mathrm{DPPH}$ radical scavenging, suggesting that LS can act as a preservative for food, medicine, or cosmetics because it had excellent antibacterial properties against Bacillus cereus. Meanwhile, LA is used as a cosmetic ingredient because it possesses anti-aging, antioxidative, and inhibitory properties on tyrosinase activity (Hsu et al., 2007). The three plants' phenolic compounds had a high radical scavenging activity (Kadoma \& Fujisawa, 2008), and the composite, as a cosmetic formulation, could prevent the overproduction of melanin through its anti-oxidative properties.

\section{Qualitative and quantitative analysis of marker compounds.}

The study was conducted to predict several components to determine the marker compounds of EtOH extracts of LS, OJ, and LA. CGA, ECG, and RMA were selected, which were detected with higher content from the standard calibration curves obtained through liquid chromatography/mass spectrometry (LC/MS) analysis (Ham et al., 2018). The structures of these compounds are shown in Figure 1. Three marker compounds were analyzed with water containing $0.1 \%$ formic acid and acetonitrile made up of $0.1 \%$ formic acid through HPLC-DAD.

\section{Establishment of simultaneous analysis conditions}

The marker compounds demonstrated showed high absorbance at $213 \mathrm{~nm}, 326 \mathrm{~nm}$, and $329 \mathrm{~nm}$ on the HPLC-DAD analysis's UV absorbance spectrum (Figure 3). In Figure 2A, a mixture of the standards' chromatogram showed that the CGA, ECG, and RMA peaks showed different retention times (27.78 min, 34.50 $\mathrm{min}$, and $39.23 \mathrm{~min}$, respectively) without interference. These results demonstrated that the conditions of simultaneous analysis of three marker compounds were established. 
A Mix. standards
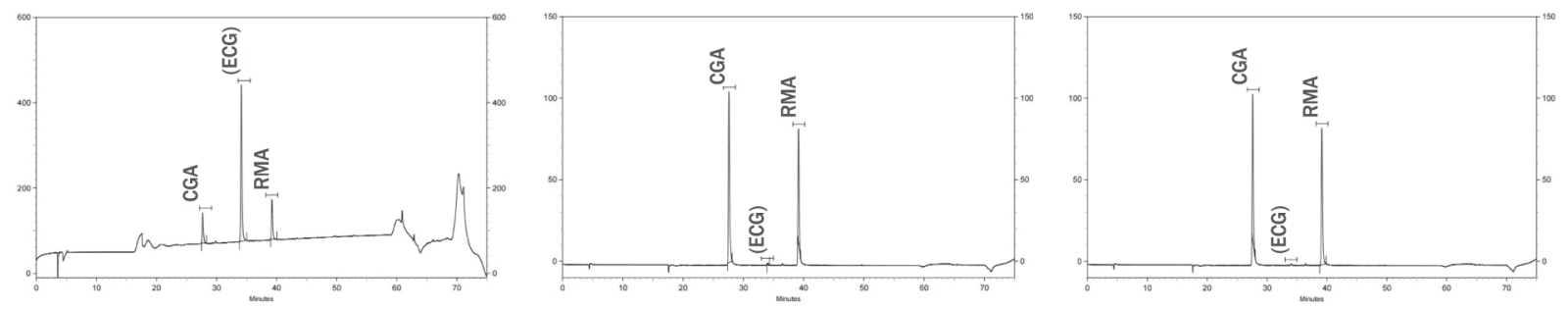

\section{B LOL}

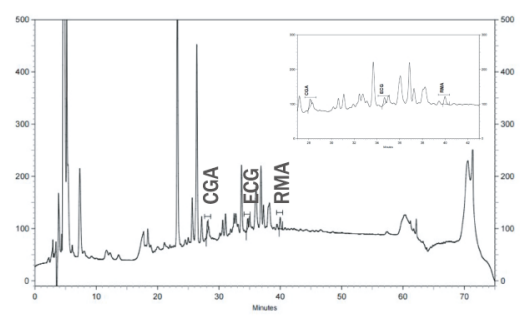

$213 \mathrm{~nm}$

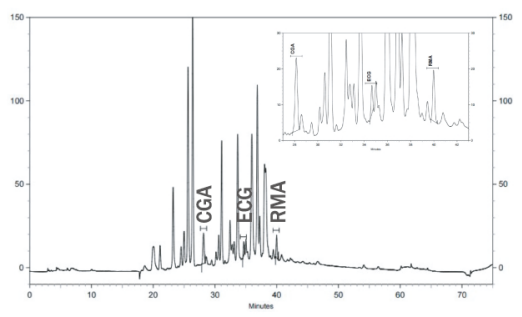

$326 n m$

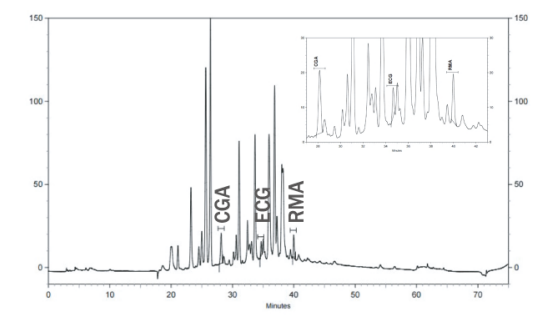

$329 \mathrm{~nm}$

Figure 2. HPLC profile in the simultaneous analysis of the LOL.

(A) Representative chromatogram of standards mixture solution at $213 \mathrm{~nm}, 326 \mathrm{~nm}$, and $329 \mathrm{~nm}$, respectively. (B) Representative chromatogram of LOL, cosmetic composite at $213 \mathrm{~nm}, 326 \mathrm{~nm}$, and $329 \mathrm{~nm}$, respectively. CGA, chlorogenic acid; ECG, epicatechin gallate; RMA, rosmarinic acid; LOL, mixture of Ligularia stenocelphala, Orostachys japonica and Lavandula angustifolia.

\section{Specificity}

As shown in Figure 2B, the LOL composite's chromatogram showed that the retention times of the three marker components' peaks from LOL were identical to the retention times of the standard materials. This result determined that CGA, ECG, and RMA were present in the LOL composite because its peaks on the UV absorbance spectrum are identical to the UV spectrum of standard products (Figure 3). Meanwhile, the chromatograms at $213 \mathrm{~nm}$ showed an increase in peak intensity with increasing absorbance of ECG, and the chromatograms at $326 \mathrm{~nm}$ and 329 $\mathrm{nm}$ revealed an increase in peak intensity with increasing CGA and RMA absorbance. The results confirmed that each marker component's peak increased on the LOL chromatogram when each standard material was injected with LOL as an internal standard (data not shown). Figure 2B also shows several peaks beside the marker components.

\section{Linearity, LOD and LOQ}

Linear regression analysis of each marker compound was evaluated using $\mathrm{R}^{2}$, range, LOD, and LOQ (Table 2). All three marker compounds exhibited linearity with a correlation coefficient of $\mathrm{R}^{2}>0.9997$ in a $1-100 \mu \mathrm{g} / \mathrm{mL}$ concentration range. The LOD of CGA, ECG, and RMA were determined to be 0.83 $\mu \mathrm{g} / \mathrm{mL}, 0.33 \mu \mathrm{g} / \mathrm{mL}$, and $0.20 \mu \mathrm{g} / \mathrm{mL}$, respectively, and the LOQ range of CGA, ECG, and RMA were $2.51 \mu \mathrm{g} / \mathrm{mL}, 0.99 \mu \mathrm{g} /$ $\mathrm{mL}$, and $0.61 \mu \mathrm{g} / \mathrm{mL}$, respectively.

Table 1. Concentration $\left(\mathbf{R C}_{50}\right)$ value of 2,2-diphenyl-1-picrylhydrazyl (DPPH) scavenging activity

\begin{tabular}{cc}
\hline Sample name & $\mathrm{RC}_{50}$ value $(\mu \mathrm{g} / \mathrm{mL})$ \\
LS & $88.14 \pm 5.6$ \\
OJ & $48.21 \pm 4.0$ \\
LA & $74.40 \pm 1.7$ \\
LS+OJ+LA (LOL) & $67.73 \pm 2.6$ \\
L-ascorbic acid & $19.81 \pm 4.7$ \\
\hline
\end{tabular}

$\mathrm{RC}_{50}$ value: concentration required for $50 \%$ reduction of DPPH at 30 min reaction; DPPH, 2,2-diphenyl-1 picrylhydrazyl; LS, Ligularia stenocephala; OJ, Orostachys japonica; LA, Lavandula angustifolia; LOL, mixture of LS, OJ, and LA. 
A Mix. standards
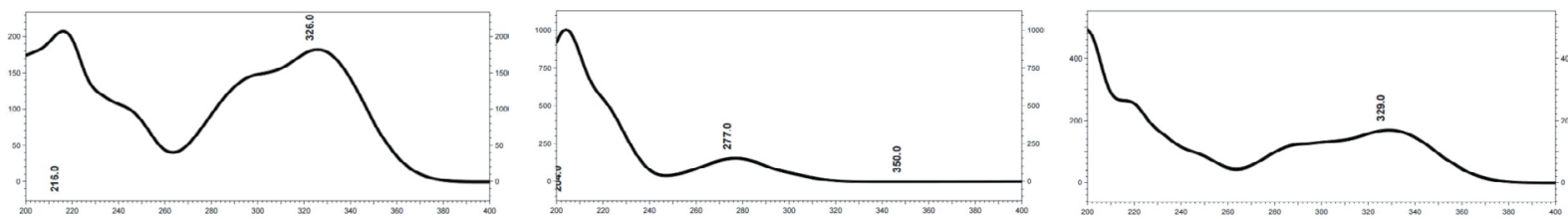

B LOL

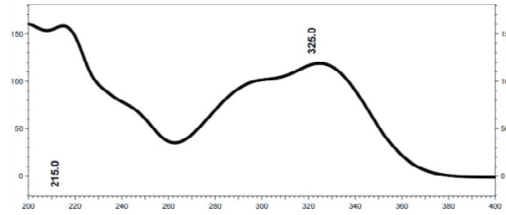

Chlorogenic acid

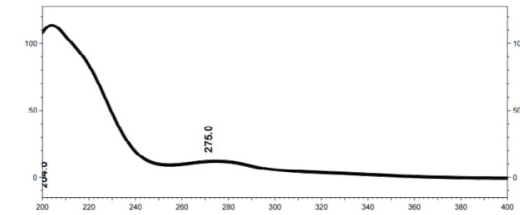

Epicatechin gallate

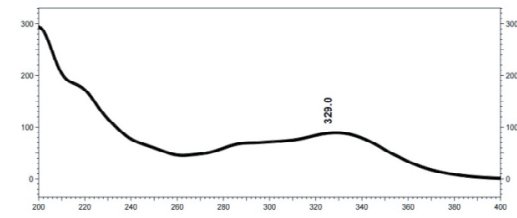

Rosmarinic acid

Figure 3. UV spectra of standard marker compound and marker compound in LOL

(A) UV Spectra of three marker compound from the standard mixture and (B) from the mixture of three herbs, LOL (Ligularia stenocelphala, Orostachys japonica,and Lavandula angustifolia).

Table 2. HPLC calibration data for CGA, ECG, and RMA

\begin{tabular}{lcccccc}
\hline Compound & $\begin{array}{c}\text { Linear range } \\
(\mu \mathrm{g} / \mathrm{mL})\end{array}$ & $\begin{array}{c}\mathrm{t}_{\mathrm{R}} \\
(\mathrm{min})\end{array}$ & Regression equation & $\begin{array}{c}\text { Linearity } \\
\left(\mathrm{R}^{2}\right)\end{array}$ & $\begin{array}{c}\mathrm{LOD} \\
(\mu \mathrm{g} / \mathrm{mL})\end{array}$ & $\begin{array}{c}\mathrm{LOQ} \\
(\mu \mathrm{g} / \mathrm{mL})\end{array}$ \\
CGA & $1-100$ & 27.78 & $\mathrm{y}=461543 \mathrm{x}+51056$ & 0.9999 & 0.83 & 2.51 \\
ECG & $1-100$ & 34.50 & $\mathrm{y}=651351 \mathrm{x}+36542$ & 0.9997 & 0.33 & 0.99 \\
RMA & $1-100$ & 39.23 & $\mathrm{y}=195405 \mathrm{x}-41670$ & 1 & 0.20 & 0.61 \\
\hline
\end{tabular}

$t_{R}$, retention time; LOD, limit of detection; LOQ, limit of quantification; CGA, chlorogenic acid; ECG, epicatechin gallate; RMA, rosmarinic acid.

Table 3. Recovery levels of CGA, ECG, and RMA

\begin{tabular}{|c|c|c|c|c|}
\hline Compound & Theoretical amount $(\mu \mathrm{g})$ & Detected amount $(\mu \mathrm{g})$ & Recovery (\%) & RSD (\%) \\
\hline \multirow{3}{*}{ CGA } & 1 & 1.17 & 117.52 & 1.38 \\
\hline & 50 & 51.00 & 102.00 & 0.21 \\
\hline & 100 & 117.78 & 117.78 & 0.48 \\
\hline \multirow{3}{*}{ ECG } & 1 & 0.94 & 94.40 & 1.53 \\
\hline & 50 & 54.05 & 108.06 & 0.84 \\
\hline & 100 & 96.39 & 96.39 & 1.95 \\
\hline \multirow{3}{*}{ RMA } & 1 & 1.07 & 107.05 & 1.41 \\
\hline & 50 & 47.05 & 94.10 & 0.66 \\
\hline & 100 & 93.79 & 93.79 & 1.35 \\
\hline
\end{tabular}

RSD, relative standard deviation; CGA, chlorogenic acid; ECG, epicatechin gallate; RMA, rosmarinic acid.

Table 4. Accuracy and precision data for the quantitative determination of CGA, ECG, and RMA

\begin{tabular}{lccccc}
\hline & \multicolumn{2}{c}{ Intra-day $(\mathrm{n}=3)$} & \multicolumn{2}{c}{ Inter-day $(\mathrm{n}=3)$} \\
\cline { 2 - 3 } \cline { 5 - 5 } CGA & Accuracy $(\%)$ & Precision (RSD \%) & Accuracy (\%) & Precision (RSD \%) \\
ECG & 107.06 & 1.77 & 110.39 & 1.09 \\
RMA & 102.25 & 1.42 & 104.03 & 0.72 \\
\hline
\end{tabular}

RSD, relative standard deviation; CGA, chlorogenic acid; ECG, epicatechin gallate; RMA, rosmarinic acid. 
Table 5. Analysis of the content of CGA, ECG, and RMA in extracts

\begin{tabular}{lccc}
\hline & $\mathrm{t}_{\mathrm{R}}(\mathrm{min})$ & Contents $(\mu \mathrm{g} / \mathrm{ml})$ & $\mathrm{RSD}(\%)$ \\
CGA & 27.78 & $13.99(1.4 \%)$ & 1.54 \\
ECG & 34.50 & $8.28(0.8 \%)$ & 0.76 \\
RMA & 39.23 & $8.40(0.8 \%)$ & 1.09 \\
\hline
\end{tabular}

$t_{R}$, retention time; RSD, relative standard deviation; CGA, chlorogenic acid; ECG, epicatechin gallate; RMA, rosmarinic acid.

\section{Recovery}

As shown in Table 3, the recovery test results measured after adding three concentrations (low, medium, and high) of each marker standard to the extracts, showed that the recovery of CGA was $102.00 \%-117.78 \%$, and the relative standard deviation ranged $0.21 \%-1.38 \%$. The ECG recovery rate was $94.40 \%-108.06 \%$, and its relative standard deviation was around $0.84 \%-1.95 \%$. Meanwhile, RMA showed a recovery rate between $93.79 \%-107.05 \%$ and a relative standard deviation of $0.66 \%-1.41 \%$. The recovery data of all three compounds were between $93.79 \%$ and $117.78 \%$ and had RSD values less than $1.95 \%$, demonstrating this method's reliability under established conditions

\section{Accuracy and precision}

The method's accuracy and precision were evaluated using triplicate analysis once a day over three days, and intraday accuracy of CGA, ECG, and RMA was $107.06 \%$, 102.25\%, and $92.24 \%$, respectively. Conversely, inter-day accuracy was $110.39 \%, 104.03 \%$, and $89.94 \%$ for CGA, ECG, and RMA, respectively. The recovery rates of all three marker compounds were between $89.94 \%$ and $110.39 \%$, which are within $20 \%$ of the reference values of the Ministry of Food and Drug Safety's guidelines. All three markers had a range of $0.80 \%-1.77 \%$ for intraday RSD, and their inter-day RSD had a range of $0.72 \%-$ $1.42 \%$. These results reflect the guidelines' RSD of less than $5 \%$ (Table 4). Table 5 outlines the results of the quantitative analysis of the LOL composite's marker components, where CGA content was $13.99 \mu \mathrm{g} / \mathrm{mg}$ (1.4\%), ECG was $8.28 \mu \mathrm{g} / \mathrm{mg}(0.8 \%)$, and RMA was $8.40 \mu \mathrm{g} / \mathrm{mg}(0.8 \%)$ with $0.76 \%-1.54 \% \mathrm{RSD}$. This validation method can control the quality of the cosmetic ingredients, such as LS, OJ, and LA, registered on INCI.

\section{Conclusion}

To develop a complex composition of natural cosmetic materials, 50\% EtOH extracts of LS, OJ, and LA-which have relatively high DPPH radical scavenging abilities-were selected, and CGA, ECG, and RMA were identified as marker compounds. The HPLC-DAD method was used to analyze the marker compounds in the LOL composite, and validation through linearity, accuracy, and precision measurements was established. The contents of the three marker compounds were $13.99 \mu \mathrm{g} / \mathrm{mg}$ CGA, $8.28 \mu \mathrm{g} / \mathrm{mg}$ ECG, and $8.40 \mu \mathrm{g} / \mathrm{mg}$ RMA, and the results of the analysis could be used to improve quality control for natural cosmetics. Further analysis of other physiological activities is necessary to develop the LOL composite as a superior natural cosmetic composition.

\section{Acknowledgements}

This work was supported by the Korea Institute of Planning and Evaluation for Technology in Food, Agriculture, Forestry and Fisheries (IPET) through the Agriculture, Forestry and Livestock Food Research and Development project, funded by the Ministry of Agriculture, Food and Rural Affairs (MAFRA) (Grant number: 317024054SB020). The authors would also like to thank the Namwon City Cosmetic Industry Support Center for supplying the extract used in the study.

\section{Author's contribution}

JEK, ACS, JYJ and JYL contributed equally to this work. JYL supervised the project, and JEK, ACS, JYJ performed experimental design and analysis for HPLC analysis with the help of JYL. JYL and JEK wrote the manuscript together.

\section{Author details}

Ju Eun Kim (Ph.D), Department of Pharmacy, Woosuk University, 443, Samnye-ro, Samnye-eup, Jeollabuk-do 55338, Korea; Abinash Chandra Shrestha (MS), Department of Pharmacy, Woosuk University, 443, Samnye-ro, Samnye-eup, Jeollabuk-do 55338, Youn Jeong Jo (Gradutre student), Department of Pharmacy, Woosuk University, 
443, Samnye-ro, Samnye-eup, Jeollabuk-do 55338, Jae Yoou Leem (Professor), Department of Pharmacy, Woosuk University, 443, Samnye-ro, Samnye-eup, Jeollabuk-do 55338 , Korea.

\section{References}

Andrys D, Adaszyńska-Skwirzyńska M, Kulpa D. Essential oil obtained from micropropagated lavender, its effect on HSF cells and application in cosmetic emulsion as a natural protective substance. Natural Product Research, 32: 849-853, 2018.

Blois MS. Antioxidant determinations by the use of a stable free radical. Nature, 181: 1199-1200, 1958.

Carrasco A, Martinez-Gutierrez R, Tomas V, Tudela J. Lavandula angustifolia and Lavandula latifolia essential oils from Spain: aromatic profile and bioactivities. Planta Medica, 82: 163-170, 2016.

Cavanagh HMA, Wilkinson JM. Biological activities of lavender essential oil. Phytotherapy Research, 16: 301-308, 2002.

Chanchal D, Swarnlata S. Novel approaches in herbal cosmetics. Journal of Cosmetic Dermatology, 7: 89-95, 2008.

Chang IS. Present and future of functional cosmetics. Journal of the Society of Cosmetic Scientists, 29: 149-178, 2003.

Choi SY, Chung MJ, Sung NJ. Studies on the antioxidative ability of methanol and water extracts from Orostachys japonicus A. Berger according to harvest times. The Korean Journal of Food and Nutrition, 21: 157-164, 2008.

Czerwińska ME, Kalinowska E, Popowski D, Bazylko A. Lamalbid, chlorogenic acid, and verbascoside as tools for standardization of Lamium album flowers-development and validation of HPLC-DAD method. Molecules, 25: 1721, 2020.

Espinosa-Leal CA, Garcia-Lara S. Current methods for the discovery of new active ingredients from natural products for cosmeceutical applications. Planta Medica, 85: 535551, 2019.

Elansary HO, Szopa A, Klimek-Szczykutowicz M, Jafernik K, Ekiert $\mathrm{H}$, Mahmoud EA, Abdelmoneim Barakat A, ElAnsary DO. Mammillaria species-polyphenols studies and anti-cancer, anti-oxidant, and anti-bacterial activities. Molecules, 25: 131, 2019.
Ha JH, Kim AR, Lee KS, Xuan SH, Kang HC, Lee DH, Cha MY, Kim HJ, An M, Park SN. Anti-aging activity of Lavandula angustifolia extract fermented with Pediococcus pentosaceus DK1 isolated from Diospyros kaki fruit in UVB-irradiated human skin fibroblasts and analysis of principal components. Journal of Microbiology and Biotechnology, 29: 21-29, 2019.

Ham HN, Shrestha AC, Kim JE, Lee TB, Yoo BW, Kim MS, Kim KS, Cha JS, Lee YM, Kim JY, et al. Simultaneous analysis of the compounds of natural cosmetic resources containing Chrysanthemum zawadskii, Perilla frutescens, Rosa multiflora and their anti-oxidative activity. Korean Journal of Pharmacognosy, 49: 312-321, 2018.

Hsu CK, Chang CT, Lu, HY, Chung YC. Inhibitory effects of the water extracts of Lavendula sp. on mushroom tyrosinase activity. Food Chemistry, 105: 1099-1105, 2007.

Hur JM, Park JC. Effects of the aerial parts of Orostachys japonicus and its bioactive component on hepatic alcoholmetabolizing enzyme system. Journal of Medicinal Food, 9: 336-341, 2006.

Im DS, Lee JM, Lee J, Shin HJ, No KT, Park SH, Kim K. Inhibition of collagenase and melanogenesis by ethanol extracts of Orostachys japonicus A. Berger: possible involvement of Erk and Akt signaling pathways in melanoma cells. Acta Biochimica et Biophysica Sinica (Shanghai), 49: 945953, 2017.

Kadoma Y, Fujisawa S. A comparative study of the radicalscavenging activity of the phenolcarboxylic acids caffeic acid, p-coumaric acid, chlorogenic acid and ferulic acid, with or without 2-mercaptoethanol, a thiol, using the induction period method. Molecules, 13: 2488-2499, 2008.

Kim HJ, Lee JY, Kim SM, Park DA, Jin C, Hong SP, Lee YS. A new epicatechin gallate and calpain inhibitory activity from Orostachys japonicus. Fitoterapia, 80: 73-76, 2008.

Kim JY, Jung EJ, Won YS, Lee JH, Shin DY, Seo KI. Cultivated Orostachys japonicus induces apoptosis in human colon cancer cells. Korean Journal of Food Science and Technology, 44: 317-323, 2012a.

Kim KH, Kim NY, Kim SH, Han IA, Yook HS. Study on antioxidant effects of fractional extracts from Ligularia stenocephala leaves. Journal of the Korean Society of Food Science and Nutrition, 41: 1220-1225, 2012b.

Lee BI, Agung N, Moch SB, Choi J, Lee KR, Kim WB, Lee KT, 
Lee JD, Park HJ. Anti-ulcerogenic effect and HPLC analysis of the caffeoylquinic acid-rich extract from Ligularia stenocephala. Biological \& Pharmaceutical Bulletin, 33: 493-497, 2010.

Mellou F, Varvaresou A, Papageorgiou S. Renewable sources: applications in personal care formulations. International Journal of Cosmetic Science, 41: 517-525, 2019.

NIFDS. Drug validation guidelines. National Institute of Food and Drug Safety Evaluation, Seoul, pp1-23, 2015.

Nohynek GJ, Antignac E, Re T, Toutain H. Safety assessment of personal care products/cosmetics and their ingredients. Toxicology and Applied Pharmacology, 243: 239-259, 2010.

Papageorgiou S, Varvaresou A, Panderi I, Giannakou M, Spiliopolou C, Athanaselis S. Development and validation of a reversed-phase high-performance liquid chromatographic method for the quantitation and stability of $\alpha$-lipoic acid in cosmetic creams. International Journal of Cosmetic Science, 42: 221-228, 2020.

Roh EJ, Kim YS, Kim BG. Effect of antioxidation and inhibition of melanogenesis from Ligularia stenocephala extract.
Journal of the Korean Applied Science and Technology, 26: 87-92, 2009.

Todoya K, Yaoita Y, Kikuchi M. Three new dimeric benzofuran derivatives from the roots of Ligularia stenocephala MATSUM. et KOIDZ. Chemical \& Pharmaceutical Bulletin, 53: 1555-1558, 2005.

Xiao W, Peng Y, Tan Z, Lv Q, Chan CO, Yang J, Chen S. Comparative evaluation of chemical profiles of pyrrosiae folium originating from three pyrrosia species by HPLCDAD combined with multivariate statistical analysis. Molecules, 22: 2122, 2017.

Yoon Y, Kim KS, Hong SG, Kang BJ, Lee MY, Cho DW. Protective effects of Orostachys japonicus A. Berger (Crassulaceae) on $\mathrm{H}_{2} \mathrm{O}_{2}$-induced apoptosis in GT1-1 mouse hypothalamic neuronal cell line. Journal of Ethnopharmacology, 69: 73-78, 2000.

Zhao J, Xu F, Huang H, Ji T, Li C, Tan W, Chen Y, Ma L. Evaluation on bioactivities of total flavonoids from Lavandula angustifolia. Pakistan Journal of Pharmaceutical Sciences, 28: 1245-1251, 2015. 


\section{국문초록}

\section{LOL (Ligularia stenofelphala, Orostachts japonica, Lavandula anfustifola) 화장품}

\section{복합재의 Chlorogenic Acid, Epicatechin Gallate 및 Rosmarinic Acid의 동시 분석}

\section{및 항산화 활성}

김주은 ${ }^{1,2}$, 아비나쉬 찬드라 쓰레스타 ${ }^{1}$, 조윤정 ${ }^{1}$, 임재윤 ${ }^{1,2 *}$

${ }^{1}$ 우석대학교 약학과, 전라북도 완주군, 한국

${ }^{2}$ 우석대학교 스마트 융복합 라이프케어 연구소, 전라북도 완주군, 한국

목적: 천연 화장품에 대한 수요가 증가함에 따라 적절한 생산 관리 및 품질 관리가 우선 되어야 한다. Chlorogenic aicd (CGA), epicatechin gallate (ECG) 및 rosmarinic acid (RMA)을 지표성분으로 선택하여 Ligularia stenocephala (LS; 곤달비), Orostachys japonica (OJ; 와송) 및 Lavandula angustifolia (LA; 라벤더) $50 \% \mathrm{EtOH}$ 추출물이 함유 된 화장품 조성물 LOL을 검증했다. 방법: High-performance liquid chromatography with diode array (HPLC-DAD)를 사용하여 LOL (Ligularia stenofelphala, Orostachys japonica, Lavandula anfustifolia)의 세 가지 화합물을 동시에 분석했다. HPLC-DAD를 사용하여 선형성, 정확도 및 정밀도 분석 을 수행했다. 그리고 DPPH 라디칼 소거 분석을 통해 항산화 효과를 평가했다. 결과: 세 가지 추출물 모두 DPPH 라디칼 소거 효과 가 높았으며 검출 된 지표 성분은 유의 한 직선성을 나타냈다( $\left.\mathrm{R}^{2} \geq 0.9997\right) . \mathrm{CGA}, \mathrm{ECG}$ 및 RMA의 검출 한계(LOD)는 각각 $0.83 \mu \mathrm{g} /$ $\mathrm{mL}, 0.33 \mu \mathrm{g} / \mathrm{mL}$ 및 $0.20 \mu \mathrm{g} / \mathrm{mL}$ 이며, $\mathrm{CGA}$, ECG 및 RMA의 정량 한계(LOQ)는 각각 $2.51 \mu \mathrm{g} / \mathrm{mL}, 0.99 \mu \mathrm{g} / \mathrm{mL}$ 및 $0.61 \mu \mathrm{g} / \mathrm{mL}$ 이 다. 분석법 검증 결과, $\mathrm{CGA}, \mathrm{EOG}$ 및 $\mathrm{RMA}$ 의 허용 가능한 정밀도(일중 및 일간 정밀도)는 각각 $1.77,1.42,0.80 \%$ 및 $1.09,0.72$, $1.42 \%$ 이고, 회수율은 각각 $102.00 \%-117.78 \%, 94.40 \%-108.06 \%$ 및 $93.79 \%-107.05 \%$ 이다. 결론: 3 개의 지표 성분의 함량 은 각각 $13.99 \mu \mathrm{g} / \mathrm{mL}$ CGA, $8.28 \mu \mathrm{g} / \mathrm{m} \mathrm{ECG}$ 및 $8.40 \mu \mathrm{g} / \mathrm{mL}$ RMA 이다. 또한 본 연구는 개발 된 방법이 LOL 화장품 조성물 품질 관리 프로세스를 검증 할 수 있음을 시사한다.

핵심어: 곤달비, 와송, 라벤더, HPLC-DAD, 밸리데이션

This work was supported by the Korea Institute of Planning and Evaluation for Technology in Food, Agriculture, Forestry and Fisheries (IPET) through the Agriculture, Forestry and Livestock Food Research and Development project, funded by the Ministry of Agriculture, Food and Rural Affairs (MAFRA) (Grant number: 317024054SB020). The authors would also like to thank the Namwon City Cosmetic Industry Support Center for supplying the extract used in the study.

\section{참고문헌}

김재용, 정은정, 원영선, 이주혜, 신동영, 서권일. 인체 대장암 세포주 SW480에서 재배 와송의 세포 사멸 유도 효과. 한국 식품과학회지, 44: 317-323, 2012.

식품의약품안전평가원. 의약품등 시험방법 밸리데이션 가이드라인. 식품의약품안정평가원, 서울, $\mathrm{pp} 1-23,2015$.

장인섭. 기능성 화장품 연구동향. 대한화장품학회지, 29: 149-178, 2003.

최선영, 정미자, 성낙주. 채취 시기에 따른 와송 추출물의 항산화 활성 연구. 한국식품영양학회지, $21: 157-164,2008$. 함하늘, 쉐레스타 아비나쉬 찬드라, 김주은, 이태범, 유병완. 산구절초, 자소엽, 찔레를 함유한 천연 화장품 소재의 다성분 동시분석과 항산화활성. 생약학회지, 49: 312-321, 2018. 


\section{中文摘要}

\section{同时分析来自LOL (Ligularia stenofelphala、Orostachts japonica、Lavandula anfustifola）化妆品复合物中的绿原酸、表儿茶素没食子酸酯和迷迭香酸及其抗 氧化活性}

金主恩 ${ }^{1,2}$, 阿比纳什 钱德拉 什雷斯塔1, 趙胤晶 ${ }^{1}$, 林載允 ${ }^{1,2 *}$

${ }^{1}$ 又石大学药学科, 全罗北道完州郡, 韩国

2智慧融合生命关怀研究所，全罗北道完州郡，韩国

目的：随着对天然化妆品需求的增加，应优先考虑妥善管理生产和质量控制。选择绿原酸(CGA)、表儿茶素没食 子酸酯(ECG)和迷迭香酸 (RMA)来验证化妆品复合物 LOL, 这是一种由 $50 \%$ 乙醇提取物的窄头胡瓜 (LS)、粳稻 (OJ) 和狭叶薰衣草的混合物（LA）。方法: 采用带二极管阵列检测器的高效液相色谱法 (HPLC-DAD) 同时分析 来自 LOL（Liguaria stenocephala、Orostachys japonica、Lavandula angustifolia）的三种 LOL 化合物。使 用 HPLC-DAD 进行线性、准确度和精密度分析，并通过 DPPH 自由基清除试验评估抗氧化作用。结果: 三种提 取物均显示出较高的 DPPH 自由基清除作用, 且检测到的标记化合物呈显着线性（ $R^{2} \geq 0.9997 ） 。 C G A 、 E C G$ 和 RMA 的检测限 (LOD) 分别为 $0.83 \mu \mathrm{g} / \mathrm{mL} 、 0.33 \mu \mathrm{g} / \mathrm{mL}$ 和 $0.20 \mu \mathrm{g} / \mathrm{mL}$ 。同时, CGA、ECG 和 RMA 的定量 限 (LOQ) 分别为 $2.51 \mu \mathrm{g} / \mathrm{mL} 、 0.99 \mu \mathrm{g} / \mathrm{mL}$ 和 $0.61 \mu \mathrm{g} / \mathrm{mL}$ 。方法验证显示, CGA、ECG 和 RMA的可接受的精 密度 (日内和日间精密度) 分别为 $1.77 、 1.42 、 0.80 \%$ 和 $1.09 、 0.72 、 1.42 \% ;$ CGA、ECG 和 RMA的回收率分别 为 $102.00 \%-117.78 \% 、 94.40 \%-108.06 \%$ 和 93.79\%-107.05\%。结论: 三种标志物的含量分别为 $13.99 \mu \mathrm{g} / \mathrm{mL}$ (CGA)、8.28 $\mu \mathrm{g} / \mathrm{mL}$ (ECG) 和 $8.40 \mu \mathrm{g} / \mathrm{mL}$ (RMA)。这项研究还表明, 所开发的方法可以验证 LOL 化妆品成分的 质量控制过程。

关键词: Ligularia stenocephala, 粳稻, 狭叶薰衣草, HPLC-DAD, 验证 
